\title{
The Abiotic Ecology and Prevalence of Palaemonid Shrimps (Crustacea: Palaemonidae) of Osse River, Edo State, Nigeria
}

\author{
Isibor Patrick Omoregie ${ }^{1 *}$ \\ ${ }^{1}$ Department of Animal and Environmental Biology, Faculty of Life Sciences, University of Benin, \\ Benin City, Nigeria.
}

Author's contribution

The sole author designed, analyzed, interpreted and prepared the manuscript.

Article Information

DOI: 10.9734/JALSI/2016/29497

Editor(s):

(1) Hayet Hammami, Fungal and Parasitic Molecular Biology Laboratory, Sfax University, Tunisia. (2) Yunjun Yan, Institute of Bioenergy and Ecology, College of Life Science and Technology, Huazhong University of Science and Technology, P.R. China.

Reviewers:

(1) Kostas Kapiris, Institute of Marine Biological Resources, Greece.

(2) M. Shubha, BMS College for Women, India.

(3) Anonymous, University of Zulia, Venezuela.

(4) Gamal Bekhet, Alexandria University, Egypt.

(5) Chee Kong Yap, Universiti Putra Malaysia, Malaysia.

Complete Peer review History: http://www.sciencedomain.org/review-history/16994

Original Research Article

Received $14^{\text {th }}$ September 2016

Accepted $12^{\text {th }}$ November 2016

Published $23^{\text {rd }}$ November 2016

\section{ABSTRACT}

Aims: To assess the relationship between the abundance of palaemonid shrimps and variation of the abiotic ecology of the river.

Study Design: Factorial design.

Place and Duration of Study: Osse River, Ovia North East Local Government Area of Edo State, Nigeria. April to December, 2015.

Methodology: Samples were collected between April and December, 2015; at night and early morning periods. All samples were collected from all stations on monthly basis to cover some part of rainy and dry seasons i.e. from April to December, 2015. Sex distribution pattern amongst the shrimp species and the ratio of male to female distribution for each species was analyzed mathematically. The sex variations across the stations were further analyzed using the Student's Ttest followed by a test of homogeneity of variance using Bartlett's F-test. The physical parameters of the water were assessed using standard methods while the chemical parameters were determined by using Hydro-lab water quality meter Electronic Probe, Hanna. 
Results: A total of 397 individuals, comprising 138 M. macrobrachion, 168 M. vollenhovenii, 27 M. felicinium, $29 \mathrm{M}$. lux, $24 \mathrm{~N}$. hastatus and $11 \mathrm{P}$. maculatus were observed in the study area. Availability of the shrimps was: $M$. vollenhovenii $>M$. macrobrachion $>M$. lux $>M$. fellicinium $>N$. hastatus $>P$. maculatus. This conforms to the observations of Adebola and Olaniyan [1] but at variance with the observations of Eniade and Bello-Olusoji [2]. Population of the female shrimps outnumbered the male in all the species captured. The depth of the aquatic environment had significant negative correlations with $M$. macrobrachion $(-0.54), M$. vollenhovenii $(-0.67), M$. felicinium (-0.77), M. lux (-0.86), N. hastatus (-0.92), and $P$. maculatus $(-0.85)$. This implies that depth is a major factor which must have influenced the abundance of the shrimps in the river. There was a significant positive correlation between nitrate and numbers of $M$. vollenhovenii $(0.69), N$. hastatus (0.56), and $P$. maculatus (0.73). Results show that abiotic factors such as $\mathrm{pH}(6.7-7.5)$, temperature $\left(27.5-28.2^{\circ} \mathrm{C}\right)$, depth $(24.5-121 \mathrm{~cm})$, and primary productivity nutrients are the major determining factors to the survival of the palaemonid shrimps. Higher cultivability was observed in $M$. vollenhovenii; followed by $M$. macrobrachion due their higher resistance to variability in the abiotic factors, this might be due to their relatively higher adaptability to tough conditions. Simulation of the values obtained at Station 2 of the study area is quite feasible and may generate optimal results in shrimp aquaculture.

Conclusion: Results show that Palaemonid shrimps are littoral organisms which are quite cultivable; particularly $M$. vollenhovenii and $M$. macrobrachion. They thrive under abiotic characteristics that can be simulated in captivity. Husbandry of the identified species in an artificial culture environment is quite feasible by consciously simulating the abiotic factors obtained at the most suitable location (Station 2). We however recommend further research into biology and feeding habits of palaemons. Result of this study has provided some information to support artificial breeding of the palaemonid shrimps for biological control of schistosomiasis and shrimp entrepreneurship.

Keywords: Palaemonid shrimps; abiotic ecology; sex ratio; population; cultivability.

\section{INTRODUCTION}

There is constant growing need for shrimp husbandry due to its unique significance in diet and evolving biological control of schistosomiasis [3]. Shrimps are a unique source of safe animal protein; in the sense that its circulatory system is haemocyanin; as opposed to animals with haemoglobin, which have been associated with health concerns in consumers. Nigerian freshwater shrimps can generally be grouped into family Atyidae, Alphedae, Hippolytidae, and Palaemonidae. However, of all the families Palaemonidae have attracted the most scientific and commercial attention due to its unique morphometrics and physiology i.e. they have relatively large body size and they are stronger than other groups hence have a higher cultivability than other families. Nigerian major Palaemonid shrimps include many groups, however the genera Macrobrachium are most reputable for relatively high commercial values. The group comprises of Macrobrachium macrobrachion (generally called brackish water prawn), M. vollenhovenii (African River prawn), M. felicinium (Niger River prawn), M. dux (Congo River prawn), Nematopalaemon hastatus, and Palaemon maculatus. These species are well represented in Osse River, Edo State, Nigeria. The largest of all is $M$. vollenhovenii which could attain $182 \mathrm{~mm}$ in standard length at adult stage; followed by $M$. macrobrachion which could grow up to $138 \mathrm{~mm}$ at adult stage.

Palaemonid shrimps are detritivorous animals which feed on epibenthic organisms such as polychaetes, molluscs and other crustaceans. Current researches aimed at establishing male shrimp population so as to ameliorate the endemicity of Bilharziasis (schistosomiasis) are still at infancy. Palaemonids are very abundant in Nigerian rivers and besides being promising agents of biological control of Mollusca of medical importance, they also serve as source of relatively cheap animal protein requirements; hence income generation for shrimpers [4] and exotic export commodity [5]. Vulnerability of these unique species to anthropogenic perturbations is however noteworthy [5]. This fact can further be buttressed by significant variability in habitat alteration tolerances of shellfish [6]; particularly relatively low tolerances of palaemons. Hence their abundance and life cycle depends greatly on the abiotic factors in their environment. Anthropogenic activities noticed around Osse River as at the period the research 
was conducted include overfishing, dredging, oil production, agricultural practices and lumbering. Researchers have explored some of the conditions in which palaemonid shrimps thrive best. Eniade and Bello-Olusoji [2] pointed out that $M$. macrobrachion, $N$. hastatus and $P$. maculatus of the Ilaje Esatuary in Ondo Sate thrive best within temperature of $27.55-28.60^{\circ} \mathrm{C}$. Only $M$. vollenhovenii can withstand wider temperature ranges. On this basis, the other species can be described as relatively stenothermal i.e. thrive within narrow temperature range. Alterations in temperature may spell doom to their survival; due to their temperature-sensitivity. M. macrobrachion and $M$. vollenhovenii have wide range salinity tolerances; hence their presence in brackish waters. Others have narrow range salinity tolerances; hence referred to as stenohaline.

Palaemonid shrimps prefer shallow waters which support the growth of floating macrophytes such as Eichhornia crassipes, Paspalum vaginatum, and Pistia stratiotes [1]. These plants provide shelter to the animals particularly during breeding activities. The floating macrophytes also render services such as temperature and $\mathrm{pH}$ regulation; as well as support proliferation of plankton which constitute the diet of the shrimps. Eniade and Bello-Olusoji [2] observed that shrimps of llaje Esatuary in Ondo thrived at pH range of 6.24 to 7.11 and mean depth of $49 \mathrm{~cm} \pm 0.26$. The depth of the breeding sites observed by Eniade and Bello-Olusoji [2] is fairly lower than depth of 67 $\mathrm{cm} \pm 0.25 \mathrm{~cm}$ observed at Oluwa Creek, Igbokoda by Adebola and Olaniyan [1]. However, both results show they are sub-lithoral shrimps. $N$. hastatus and $P$. maculatus of llaje Esatuary in Ondo [2]; and $P$. maculatus in Oluwa Creek in Igbokoda [1], all exhibited sex ratio of 1 male: 2 female. However, ratio 1 male: 5 females was observed in M. macrobrachion of Ilaje Esatuary in Ondo [2]. These ratios are at variance with 1 male: 1 female obtained in most finfishes $[7,8]$. Non-existence of shrimp aquaculture in Nigeria can be attributed to lack of information on the abiotic ecological information suitable for the sustenance of these vital species. This is due to lack of information and/ or paucity of interest of researchers on the ecology of the shrimps. Much attention has been focused on bioaccumulation of toxicants by shellfish [9] but a little attention has been given to their abiotic ecological study. The very existence of ichthyofauna depends on the stability of their abiotic ambience [10]. Perturbations of the immediate environment and alteration of habitats is liable to disrupt the sustainability [11] and threaten the biodiversity of shellfishes [12] such as shrimps. This study seeks to explore the abiotic characteristics in conjunction with abundance of Palaemons of Osse River; as a supportive information to shrimp aquaculture entrepreneurship; hence poverty alleviation.

\section{MATERIALS AND METHODS}

\subsection{Study Area}

The study area is a stretch of Osse River; a link between Benin River and Ughoton stream. It traverses from ljaw fishing camp, through Ekehuan and Gelegele; and terminates at Izedema community. It is a fresh oligotrophic water [13], with a thick tropical vegetation cover along its bank. The area encompassed is located in Ovia North-East local Government Area of Edo State; within the tropical rainforest belt of Southern Nigeria. The river lies between 596'40" E and 523'20" E; 62'0" N and 694'0" N (Fig. 1).

The geology of the study area is made up of the Benin formation which is of Miocene- recent age. The thickness is about $200 \mathrm{~m}$ [14].

The climate of the study area is a humid tropical climate; characterized by two different seasons, which are the wet and dry seasons. The wet season occurs between April and October; with a break in August and an average rainfall of 1704 $\mathrm{mm}$; with a range of $1562-1867 \mathrm{~mm}$. The dry season on the other hand lasts from November to March with a cold harmattan spell which occurs between December and January.

The average temperature is $2^{\circ} \mathrm{C}(77 \mathrm{~F})$ in the rainy season and about $28^{\circ} \mathrm{C}(82 \mathrm{~F})$ in the dry season; with a mean daily temperature ranging from $2^{\circ} \mathrm{C}$ minimum in the rainy season to $30^{\circ} \mathrm{C}$ maximum in the dry season.

The vegetation in the study area includes varieties of bamboo trees (Bambusa species), palm trees (Elaeis guineensis), and surface macrophytes such as water hyacinth (Eichornia crassipes), Paspalum vaginatum, and Pistia stratiotes which serve as habitat and the breeding grounds for the prawns. Four stations were chosen based on information associated with shrimp abundance; such as observation of abundance of aquatic plants which are shelters to the prawns and predominance of fishing activites. Dredging i.e. excavation of laterite by pay loaders and fishing activities take place 


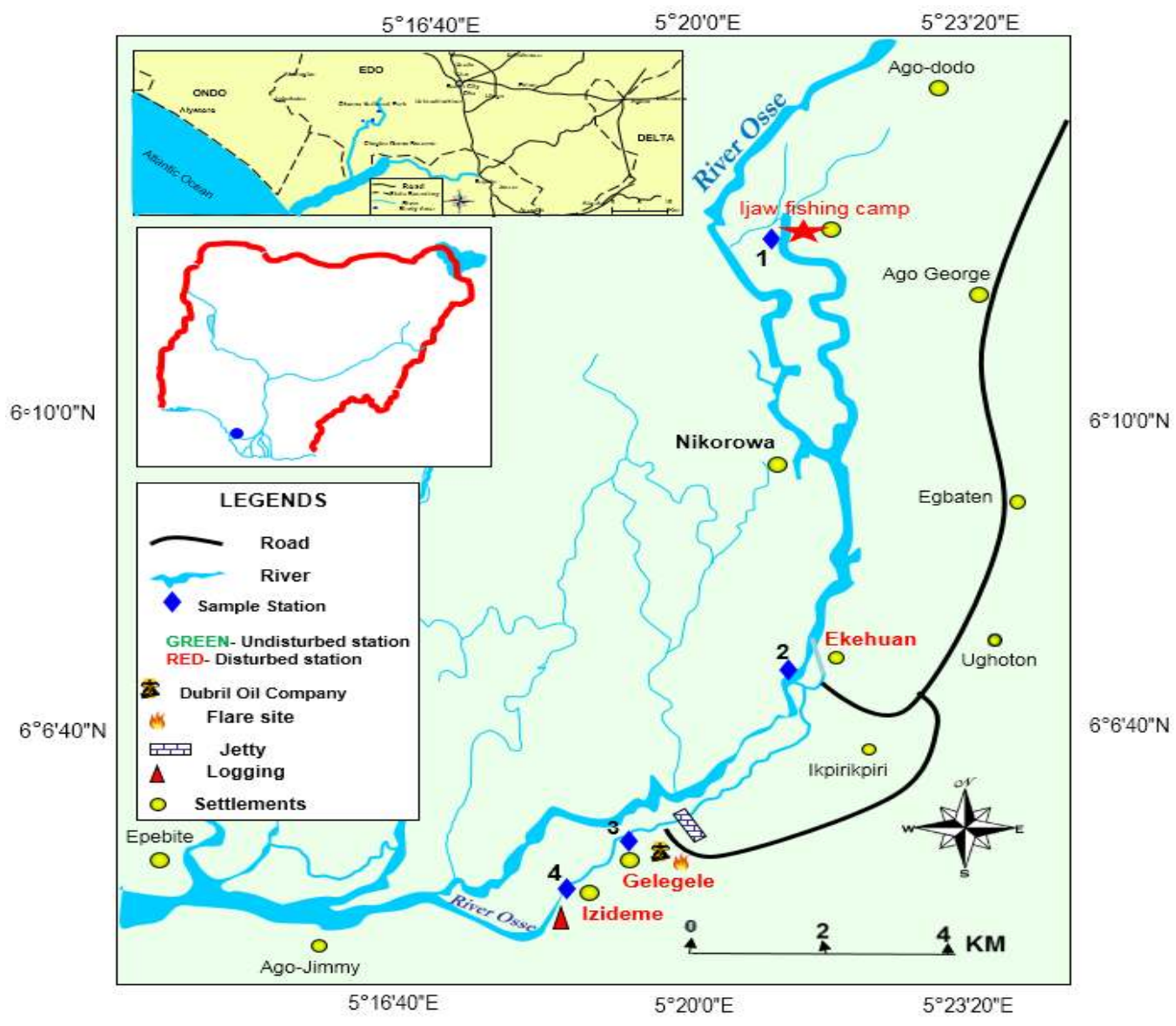

Fig. 1. Map of the study area showing sampled stations

simultaneously at Station 1 (ljaw fishing camp), few surface macrophytes were observed at this station. Station 2 (Ekehuan section) is characterized by shallow depth and abundance of surface water macrophytes. Activities such as laundering, fishing, and boating were the predominant activities observed at this station. Dubri Oil Company is situated nearby Station 3 (Gelegele section). Activities here include oil exploration, fishing and farming. Logging activity predominates the surrounding of Station 4 (Iziedema section).

\subsection{Collection and Analysis of Samples}

Samples were collected from all stations on monthly basis to cover some part of rainy and dry seasons i.e. from April to December, 2015.

\subsubsection{Collection and analysis shrimp samples}

Shrimp samples were collected from 4 stations during night periods and early mornings using local fishing gears such as woven cylindrical nonreturn valve traps, baskets and scoop nets; in conjunction with coconut, cassava and earthworm baits. The samples were preserved in four different coolers with ice; appropriately labeled to indicate the source stations and were transported immediately to the laboratory of Animal and Environmental Biology Department, University of Benin for immediate sorting, identification and counting. Palaemonid shrimps in the sites were identified by taxa to species levels, using taxonomic keys provided by FAO [15] and Powel [16]. Morphomerics such as pleura arrangement and numbers, shape of rostrum, and number of spines on the rostrum of each species were used for identification to species level [17]. Catch assessment was evaluated on weight measurement to the nearest $0.01 \mathrm{~g}$ unit using sensitive weighing balance (model pl440 w). Sex distribution pattern amongst the shrimp species and the ratio of male to female distribution for each species was analyzed using Chi Square method. The sex 
variations across the stations were further analyzed using the Students' T-test. Bartlett's Ftest was used to test for homogeneity of variance. Species composition, spatial distribution and relative abundance were used as tools to analyze the abiotic ecological variation among the stations.

\subsubsection{Collection and analysis of water samples}

Temperature $\left({ }^{\circ} \mathrm{C}\right)$ of each station was measured by immersing the tip of a mercury-in-glass thermometer into the water and left for about 2 minutes; for a stable reading. The depth $(\mathrm{cm})$ was measured with the aid of a rope with a weight of lead attached to its lower end and lowered into the water till the lead just touched the bottom. The distance between the water mark on the rope and the lead was recorded as the depth.

The analysis of water quality parameters such, $\mathrm{pH}$, total dissolved solids ( $\mathrm{mg} / \mathrm{L})$, nitrate $(\mathrm{mg} / \mathrm{L})$, phosphate $(\mathrm{mg} / \mathrm{L})$, and sulphate $(\mathrm{mg} / \mathrm{L})$ were determined in situ by using Hydro-lab water quality meter (Electronic Probe, Hanna HI98106 model). Water samples were collected in stopper bottles enclosed in black polythene bags containing ice and were immediately transported to the limnology laboratory of the Department of Animal and Environmental Biology, University of Benin, for chemical analysis of Carbonate $(\mathrm{mg} / \mathrm{L})$, dissolved oxygen $(\mathrm{mg} / \mathrm{L})$, and biological oxygen demand (mg/L); using procedures recommended by APHA [18]. Floating macrophytes were collected and taken to herbarium of the University of Benin for taxonomic identification.

\section{RESULTS AND DISCUSSION}

Total of 397 individuals, comprising of 138 M. macrobrachion, 168 M. vollenhovenii, 27 M. felicinium, 29 M. lux, $24 N$. hastatus and 11 $P$. maculatus were observed in the study area. Availability of the shrimps was: $M$. vollenhovenii $>$ M. macrobrachion > M. lux > M.fellicinium > $N$. hastatus $>P$. maculatus. This conforms to the observations of Adebola and Olaniyan [1] but varied with the observations of Eniade and BelloOlusoji [2]. Population of the female shrimps outnumbered the male in all the species captured. This conforms to the sex ratio observed among shrimps of Oluwa Creek, Igbokoda [1], Orogodo River, Delta State [3] and Ilaje Esatuary in Ondo [2]. The sex ratio patterns observed was 1 male: 4 females among $M$. macrobrachion; 1 male: 5 females among $M$. vollenhovenii and $M$. lux; 1 male: 2 females among M. felicinium, Nematopalaemon hastatus, and Palaemon maculatus. Albeit it is ecologically healthy for female population to out-number males, as this would minimize competition for mates among males and increase successful mating. However, extreme cases of sex ratio might be counter-productive. A fair margin in the population ratio has the potentials for a stable population growth i.e. 1 male: 2 females. Results show that sex ratios among $M$. felicinium, Nematopalaemon hastatus, and Palaemon maculatus of Osse River have potentials for a sustainable population growth. This sex ratio has earlier been recommended for trial induced shrimp aquaculture by Eniade and Bello-Olusoji [2].

An abrupt rise in population of the shrimps occurred between August and November (Fig. 2); particularly at Stations 1 and 2 (Fig. 3); where the $\mathrm{pH}$ of the aquatic environment was within the range of 6- 6.8 (Fig. 4). This is consistent with the $\mathrm{pH}$ range (6.24 to 7.11) within which shrimps of llaje Esatuary in Ondo thrived best [2]. This $\mathrm{pH}$ range is quite achievable; hence can be simulated in domestic shrimp husbandry.

The abrupt rise in the population of shrimps between the periods of August and October was distinct among $M$. macrobrachion and M. vollenhoveii (Figs. 2 and 3). This rise was accompanied by a stabilized temperature; between $27-27.6^{\circ} \mathrm{C}$; mainly at Stations 1 and 2 (Fig. 5). Stations 1 and 2 had more stable temperatures throughout the study period; therefore supported the shrimps. Regardless of the relatively high temperatures recorded at Stations 3 and $4, M$. macrobrachion and $M$. vollenhovenii were present, though in scanty numbers. This conforms to the established facts that these species are the toughest among others [2]. Extreme temperatures recorded at Stations 3 and 4 (Fig. 3) might be responsible for the absence of others. The stable temperature observed at Stations 1 and 2 can be attributed to the presence of floating aquatic macrophytes; which take up the carbon dioxide $\left(\mathrm{CO}_{2}\right)$ produced by the entire aquatic biota and converts it to oxygen through photosynthesis thereby stabilizing the temperature and oxygen levels for the survival of the shrimps. Table 1 shows that the mean temperatures at Stations 1 $\left(27.2^{\circ} \mathrm{C}\right)$ and $2\left(27.6^{\circ} \mathrm{C}\right)$ consistent with the 
recommendation of Eniade and Bello-Olusoji [2], and it is about the room temperature in the tropics; hence achievable for shrimp farms.

As illustrated in Fig. 6, the depth of Station 4 was significantly higher than Station $3>$ Station $1>$ Station $2(P=0.01)$. The mean dephts at Stations 1: $82 \pm 1.4 \mathrm{~cm}$, and Station 2: $72.5 \pm 3.1 \mathrm{~cm}$ (Table 1) are quite close to the most supportive depht of $67 \pm 0.25 \mathrm{~cm}$ at llaje Estuary in Ondo [2]. Although some appreciable variances exist between the current findings and that of Adebola and Olaniyan [1], Station 2 remains the closest to all previously recommended depths. Higher population of shrimps at Station 2 than other stations can be attributed to its relatively shallow depth, which supports floating macrophytes, which in turn flourishes the shrimps. There was a decline in the depths of all stations in dry season; probably due to reduced rains, which was accompanied by a general rise in the shrimp population.

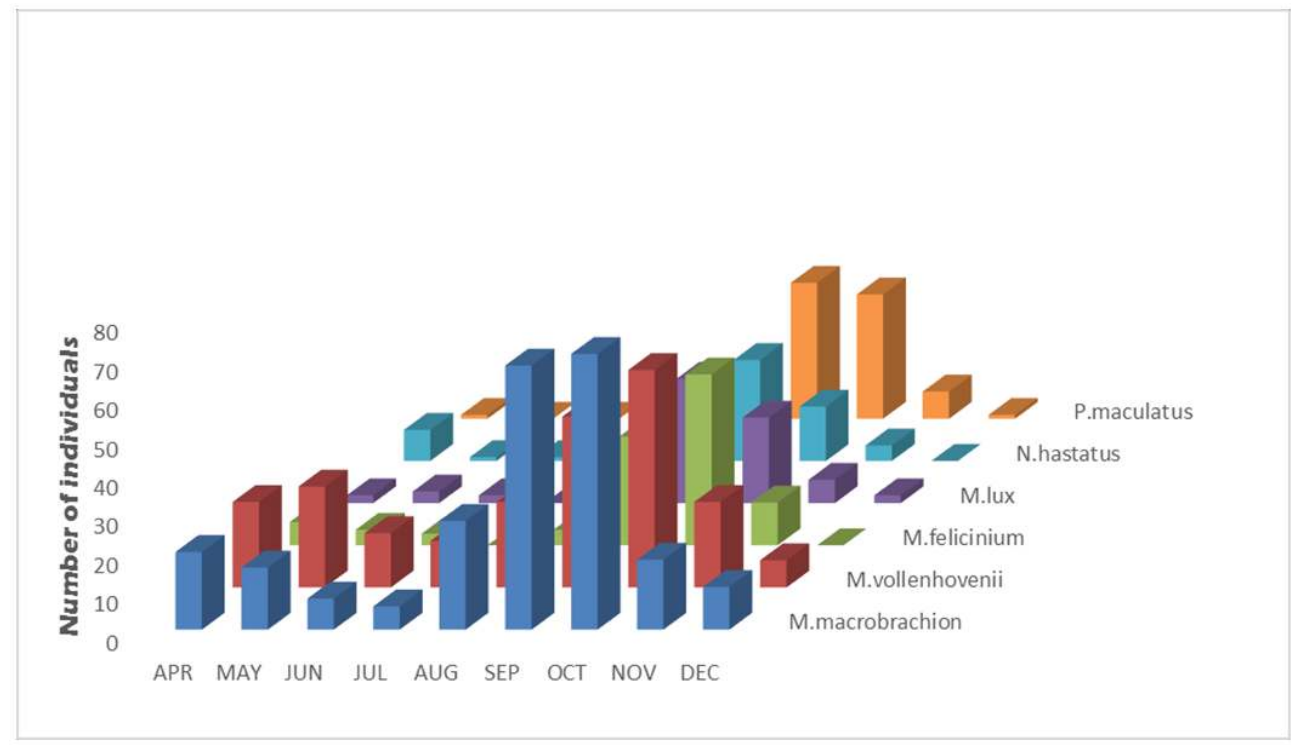

Fig. 2. Temporal variation in shrimp population

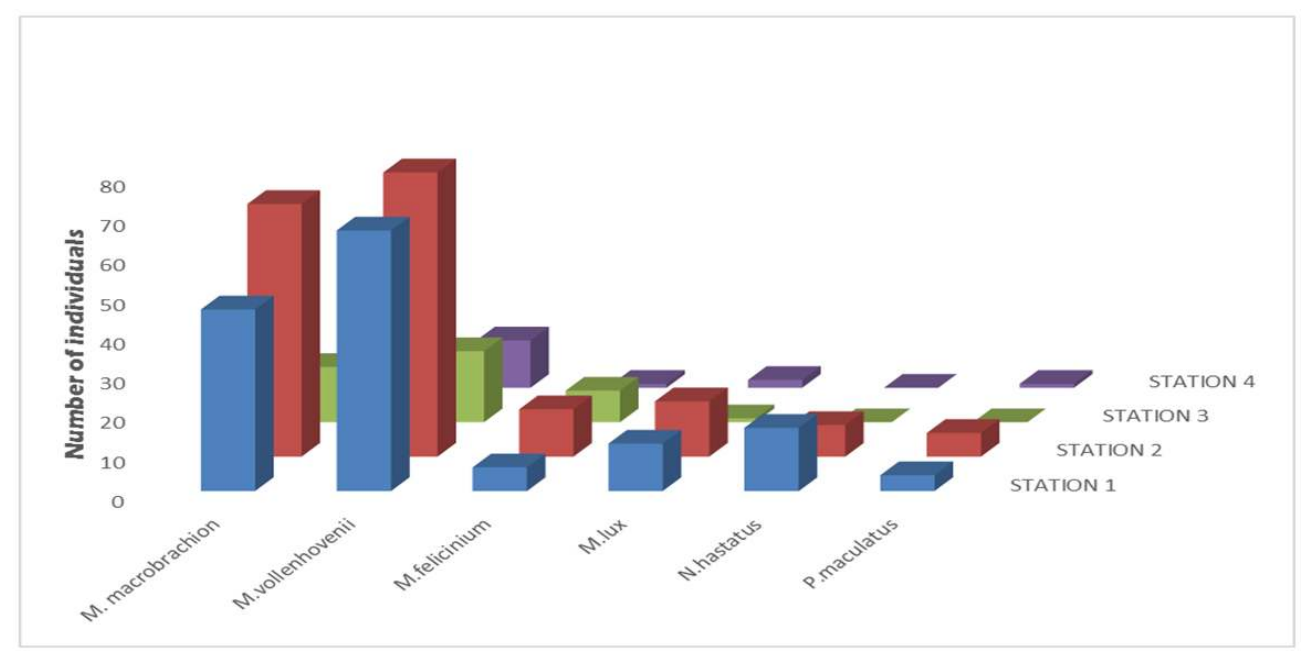

Fig. 3. Spatial distribution of shrimp population 


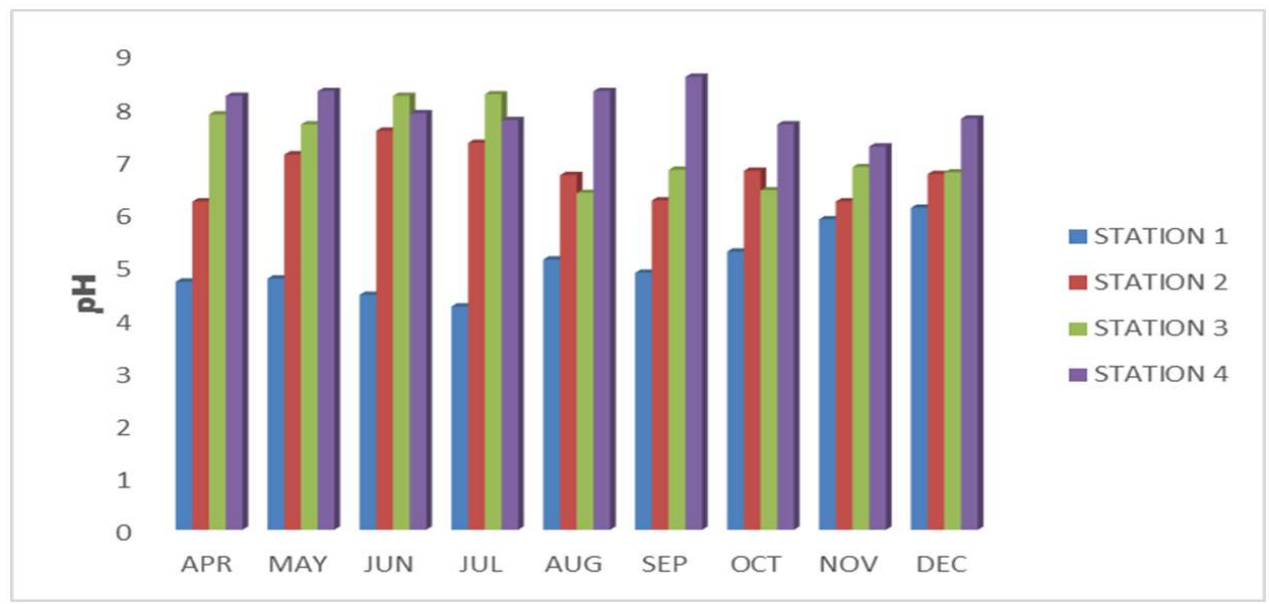

Fig. 4. Temporal variation in $\mathrm{pH}$

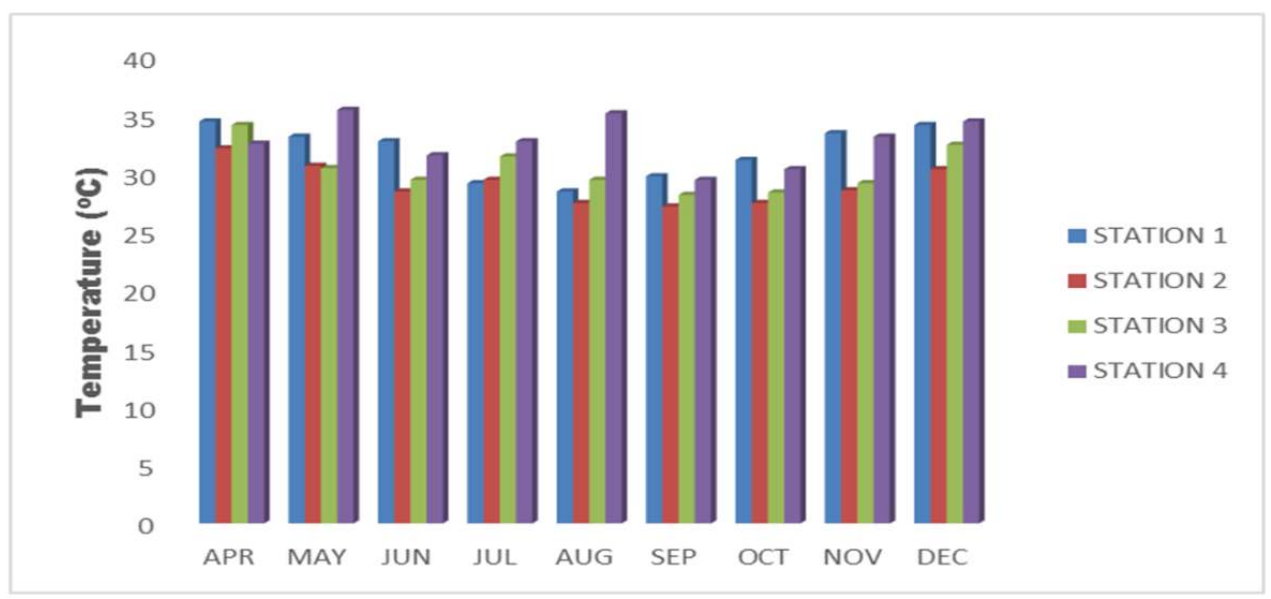

Fig. 5. Temporal variation in temperature

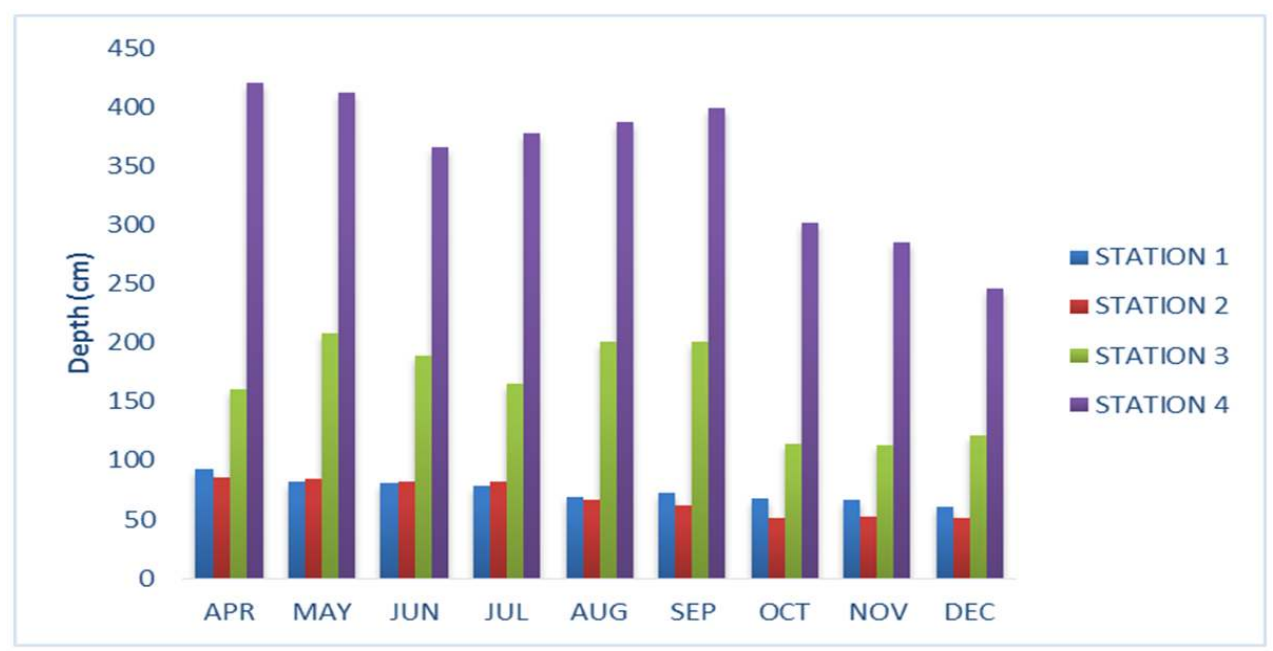

Fig. 6. Temporal variation in depth 
The dissolved oxygen at Station 2 was significantly higher than the concentration at Station $1>$ Station $4>$ Station $3(P=0.04)$. Upsurge in shrimp populations; particularly at Station 2 in August and September can also be attributed to the outstanding levels of dissolved oxygen observed at Station 2 (Fig. 7). These high concentrations over the study period can be attributed to the presence of the floating macrophytes, which were most abundant at Station 2.

Table 1 further shows that Station 2, followed by Station 1 had the highest primary productivity nutrients, which determine the availability of food [11] for the shrimps. The general levels of nitrates, phosphates and sulphates are indicative of an oligotrophic river. This complies with the findings of Imoobe and Adeyinka [13]. The concentration of nitrate at Station 2 was significantly higher than Station $4>$ Station $1>$ Station $3(P=0.01)$. The levels of phosphate at Station 2 was very much significantly higher than that at Station $1>$ Station $4>$ Station 3 $(P=0.001)$. Sulpate at Station 2 was significantly higher than that at Station $1>$ Station $3>$ Station $4(P=0.01)$. However, all the levels were below FEPA regulatory limit. The abiotic variables observed at Station 2 are most consistent with the recommended conditions for shrimp cultivation [2]. This justifies the highest population of shrimps observed at Station 2 i.e. Station $2(41 \%)>$ Station $1(32 \%)>$ Station 3 $(16 \%)>$ Station $4(11 \%)$ as illustrated in Fig. 8.

Table 2 shows that water temperature had a significant negative correlation $(-0.75)$ with dissolved oxygen and positive correlation (0.86) with biological oxygen demand. This shows that the available oxygen for the shrimps reduces with increasing temperature; thereby increasing the biological oxygen demand. Consequently, this must have been a contributing factor to the significant negative correlations of temperature with the population of $M$. felicinium (-0.81), M. Iux $(-0.76), N$. hastatus $(-0.74)$, and $P$. maculatus $(-0.84)$. Only $M$. macrobrachion and $M$. vollenhovenii showed no significant correlation with water temperature. This is an indication of higher tolerance to temperature than the others that showed significant impacts. This result conforms to earlier findings of Adebola and Olaniyan [1].

It is noteworthy that the depth of the aquatic environment also had significant negative correlations with $M$. macrobrachion (-0.54), $M$. vollenhovenii (-0.67), M. felicinium (-0.77), M. lux $(-0.86), N$. hastatus $(-0.92)$, and $P$. maculatus (0.85). This implies that depth is a major factor which must have influenced the abundance of all the shrimps in the river. The primary productivity nutrients (nitrate, phosphate and sulphate) positively correlated with the number of shrimp individuals at all stations. There was a significant positive correlation between nitrate and numbers of $M$. vollenhovenii (0.69), $N$. hastatus (0.56), and $P$. maculatus (0.73). Results shows that the palaemonid shrimps are sub-lithoral animals which are cultivable in captivity. There was also a significant positive correlation of phosphate with M. lux (0.82) and $P$. maculatus (0.77). Sulphate only showed a positive significant correlation with M. felicinium (0.76).

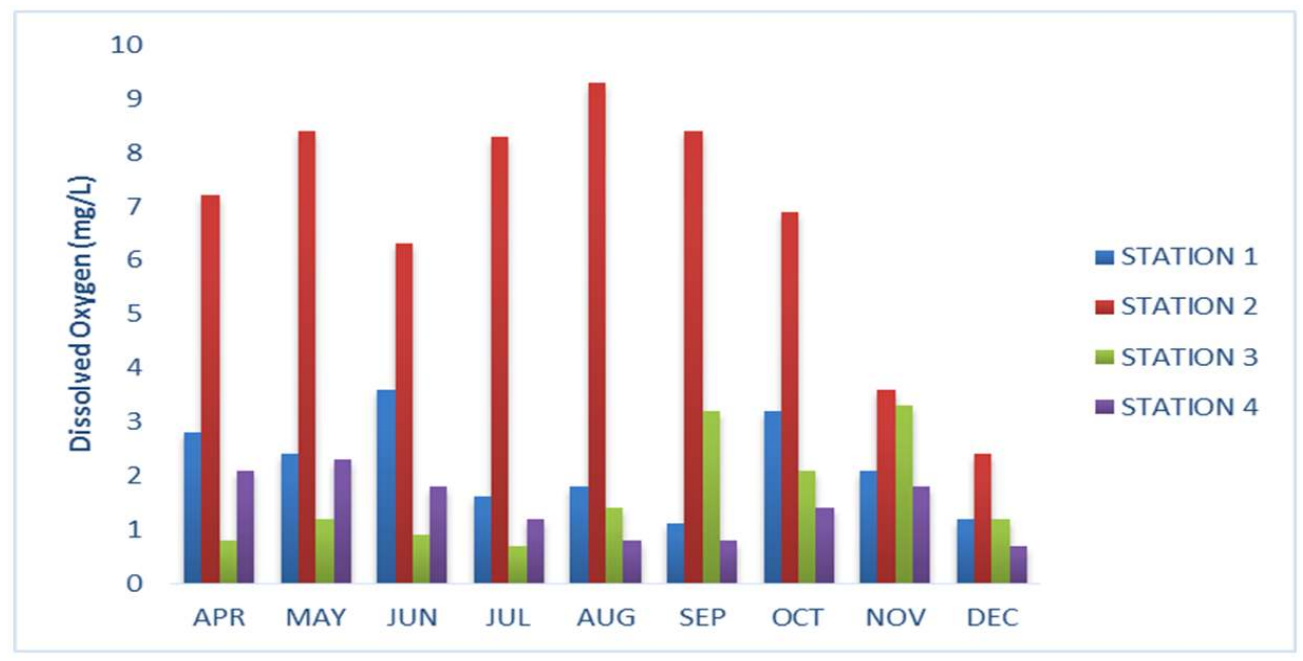

Fig. 7. Temporal variation in dissolved oxygen 
Table 1. Summary of physico-chemical properties of water

\begin{tabular}{|c|c|c|c|c|c|c|c|}
\hline Parameters & $\mathbf{N}$ & 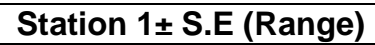 & Station $2 \pm$ S.E (Range) & Station $3 \pm$ S.E (Range) & Station $4 \pm$ S.E (Range) & $\boldsymbol{P}$ & FEPA \\
\hline $\mathrm{pH}$ & 9 & $6.8 \pm 0.1^{A}(6-7.2)$ & $6.6 \pm 0.2^{A}(6.7-7.5)$ & $6.1 \pm 0.2^{\mathrm{B}}(4.89-7.5)$ & $5.2 \pm 0.1^{\mathrm{C}}(5.3-7.5)$ & $P=0.05$ & 6- 8 \\
\hline Temp. $\left({ }^{\circ} \mathrm{C}\right)$ & 9 & $27.2 \pm 0.26^{\mathrm{C}}(27.5-31)$ & $27.6 \pm 1.07^{\mathrm{C}}(27.5-28.2)$ & $32.8 \pm 0.73^{\mathrm{A}}(24-35.3)$ & $29.8 \pm 0.86^{\mathrm{b}}(23-37.1)$ & ${ }^{*} P=0.04$ & - \\
\hline Depth $(\mathrm{cm})$ & 9 & $82 \pm 1.4^{\mathrm{C}}(22-425)$ & $72.5 \pm 3.1^{\mathrm{D}}(24.5-121)$ & $114 \pm 2.7^{\mathrm{B}}(100-455)$ & $399 \pm 3.1^{A}(167.6-738.4)$ & ${ }^{*} P=0.01$ & - \\
\hline Cond. $(\mu \mathrm{S} / \mathrm{cm})$ & 9 & $46.21^{\mathrm{B}} \pm 4.8(22-77)$ & $22.64^{\mathrm{C}} \pm 20.2(29-300)$ & $113.8^{A} \pm 33(49-670)$ & $108.5^{\mathrm{A}} \pm 39.7(20-770)$ & ${ }^{*} P=0.04$ & 400 \\
\hline $\mathrm{DO}(\mathrm{mg} / \mathrm{L})$ & 9 & $3.2 \pm 0.2^{\mathrm{B}}(0.8-3.3)$ & $6.3 \pm 0.6^{A}(3.3-11.1)$ & $1.5 \pm 0.4^{\mathrm{U}}(4.3-11.2)$ & $2.3 \pm 0.5^{C}(2.1-5.1)$ & $P=0.04$ & 7.5 \\
\hline $\mathrm{BOD}(\mathrm{mg} / \mathrm{L})$ & 9 & $3.25 \pm 0.3^{\mathrm{C}}(1.5-5.2)$ & $5.19 \pm 0.9^{\AA}(1.6-12.3)$ & $4.39 \pm 0.7^{\dot{B}}(1.7-10.5)$ & $4.62 \pm 0.7^{\dot{B}}(1.7-12.9)$ & $P=0.04$ & 30 \\
\hline $\mathrm{TDS}(\mathrm{mg} / \mathrm{L})$ & 9 & $34.8 \pm 1.4(23.5-45.5)$ & $38.2 \pm 10.1(13.5-180)$ & $39 \pm 16.7(24.7-340)$ & $33.5 \pm 20.12(10-390)$ & $P=0.09$ & 2000 \\
\hline Nitrate (mg/L) & 9 & $3.12 \pm 0.04^{B}(1.5-4.6)$ & $8.47 \pm 0.06^{A}(2.1-4.9)$ & $1.21 \pm 0.07^{\mathrm{D}}(0.1-2.2)$ & $2.32 \pm 0.11^{\mathrm{C}}(1.6-3.6)$ & ${ }^{*} P=0.01$ & 20 \\
\hline Phosphate (mg/L) & 9 & $3.2 \pm 11.02^{\mathrm{B}}(0.7-4.8)$ & $4.5 \pm 4.91^{\mathrm{A}}(2.9-6.5)$ & $1.22 \pm 4.04^{\mathrm{C}}(0.8-2.5)$ & $1.56 \pm 4.9^{\mathrm{C}}(1.1-3.5)$ & ${ }^{*} P=0.001$ & $<5$ \\
\hline Sulphate (mg/L) & 9 & $3.1 \pm 0.4^{\mathrm{B}}(1.2-3.2)$ & $5.4 \pm 1.1^{A}(1.1-9.5)$ & $2.5 \pm 0.5^{\mathrm{C}}(1.1-5.5)$ & $2.2 \pm 2.8^{\mathrm{C}}(0.1-3.5)$ & ${ }^{*} P=0.01$ & 500 \\
\hline
\end{tabular}

Note: $P$ value less than or equal to 0.05 signifies significant difference, while values greater than 0.05 signifies no significant difference. Different letters indicate significant differences, while similar letters indicate no significant differences, FEPA means Federal Environmental Protection Agency [19].

Table 2. Correlation between variables and shrimp population

\begin{tabular}{|c|c|c|c|c|c|c|c|c|c|c|c|c|c|c|c|c|}
\hline & $\mathrm{pH}$ & Tem & Depth & Cond & DO & BOD & TDS & $\mathrm{NO}_{3}$ & $\mathrm{PO}_{4}$ & $\mathrm{SO}_{4}$ & MM & MV & MF & ML & $\mathrm{NH}$ & PM \\
\hline $\mathrm{pH}$ & 1 & & & & & & & & & & & & & & & \\
\hline Temp $\left({ }^{\circ} \mathrm{C}\right)$ & 0.05 & 1 & & & & & & & & & & & & & & \\
\hline Depth (cm) & 0.04 & -0.43 & 1 & & & & & & & & & & & & & \\
\hline Cond $(\mu \mathrm{S} / \mathrm{cm})$ & 0.56 & 0.24 & 0.06 & 1 & & & & & & & & & & & & \\
\hline $\mathrm{DO}(\mathrm{mg} / \mathrm{L})$ & 0.01 & -0.75 & 0.03 & 0.06 & 1 & & & & & & & & & & & \\
\hline $\mathrm{BOD}(\mathrm{mg} / \mathrm{L})$ & 0.03 & 0.86 & 0.04 & 0.01 & 0.01 & 1 & & & & & & & & & & \\
\hline TDS(mg/L) & 0.69 & 0.03 & 0.45 & 0.43 & 0.43 & -0.12 & 1 & & & & & & & & & \\
\hline $\mathrm{NO}_{3}(\mathrm{mg} / \mathrm{L})$ & 0.12 & 0.04 & 0.34 & -0.41 & -0.41 & 0.64 & 0.06 & 1 & & & & & & & & \\
\hline $\mathrm{PO}_{4}(\mathrm{mg} / \mathrm{L})$ & 0.22 & 0.04 & 0.76 & -0.22 & -0.22 & 0.73 & 0.03 & 0.21 & 1 & & & & & & & \\
\hline $\mathrm{SO}_{4}(\mathrm{mg} / \mathrm{L})$ & 0.35 & 0.32 & 0.27 & -0.45 & -0.45 & 0.04 & 0.04 & 0.39 & 0.06 & 1 & & & & & & \\
\hline MM & 0.13 & 0.04 & -0.54 & 0.12 & 0.21 & 0.06 & 0.04 & 0.03 & 0.03 & 0.45 & 1 & & & & & \\
\hline MV & 0.66 & 0.02 & -0.67 & 0.22 & 0.04 & 0.03 & 0.01 & 0.69 & 0.04 & 0.34 & 0.06 & 1 & & & & \\
\hline MF & 0.31 & -0.81 & -0.77 & 0.35 & 0.23 & 0.04 & 0.06 & 0.12 & 0.01 & 0.76 & 0.03 & 0.33 & 1 & & & \\
\hline ML & 0.87 & -0.76 & -0.86 & 0.13 & 0.51 & 0.12 & 0.03 & 0.22 & 0.82 & 0.06 & 0.04 & 0.02 & 0.45 & 1 & & \\
\hline $\mathrm{NH}$ & 0.76 & -0.74 & -0.92 & 0.04 & 0.78 & 0.22 & 0.04 & 0.56 & 0.03 & 0.03 & 0.01 & 0.06 & 0.34 & 0.67 & 1 & \\
\hline PM & 0.04 & -0.84 & -0.85 & 0.01 & 0.88 & 0.35 & 0.04 & 0.73 & 0.77 & 0.04 & 0.44 & 0.07 & 0.76 & 0.78 & 0.65 & 1 \\
\hline
\end{tabular}

Note: $P$ value less than or equal to 0.5 signifies significant difference, while values greater than 0.5 signifies no significant difference. Emboldened numbers shows significant differences. $M M=M$. Macrobrachion, $M V=M$. vollenhovii, $M F=M$. felicinium, $M L=M$. lux, $N H=N$. hastatus, $P M=P$. maculatus 


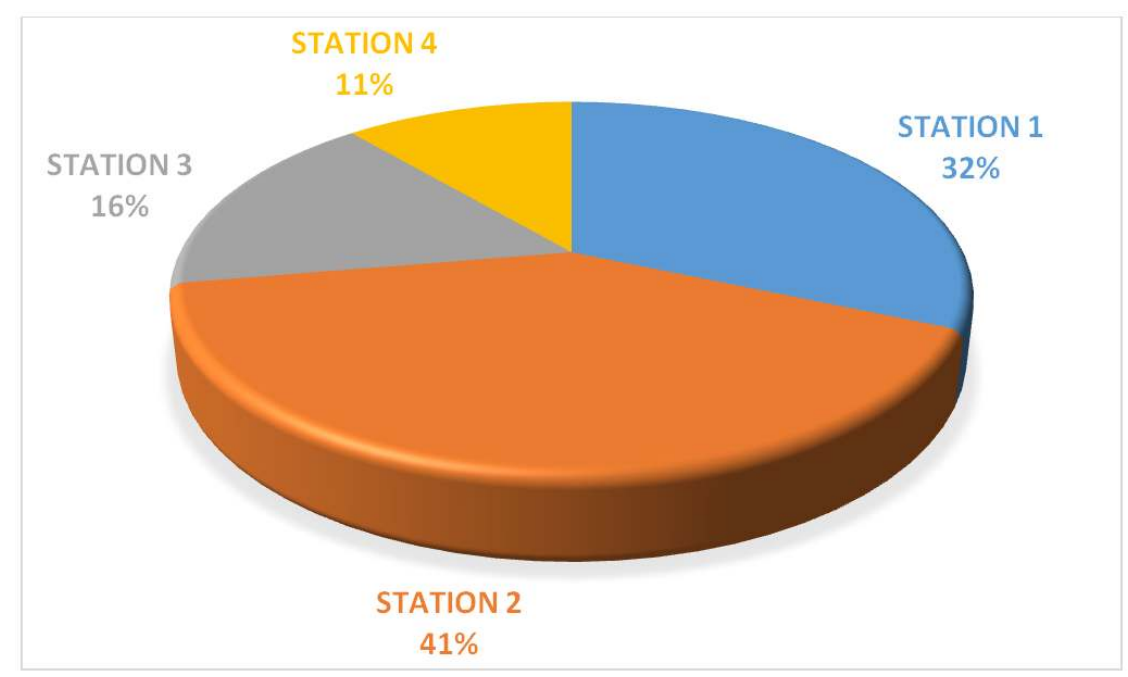

Fig. 8. Relative spatial percentage distribution of shrimps

Results show that abiotic factors such as $\mathrm{pH}$ (6.7- 7.5), temperature $\left(27.5-28.2^{\circ} \mathrm{C}\right)$, depth $(24.5-121 \mathrm{~cm})$, and primary productivity nutrients (oligotrophic) are the major determining factors to the survival of the palaemonid shrimps. Highest cultivability was observed in $M$. vollenhovenii; followed by $M$. macrobrachion due to their higher resilience and resistance to variability in the abiotic factors. Simulations of the values obtained at Station 2 of the study area are quite feasible and may generate optimal results in shrimp aquaculture.

\section{CONCLUSION}

Results show that Palaemonid shrimps are littoral organisms which are quite cultivable; particularly $M$. vollenhovenii and $M$. macrobrachion. They thrive under abiotic characteristics that can be simulated in captivity. Husbandry of the identified species in an artificial culture environment is quite feasible by consciously simulating the abiotic factors obtained at the most suitable location (Station 2). We however recommend further research into biology and feeding habits of palaemons. Result of this study has provided some information to support artificial breeding of the palaemonid shrimps for biological control of schistosomiasis and shrimp entrepreneurship; in view of poverty alleviation.

\section{ACKNOWLEDGEMENTS}

I am grateful to my parents; Chief and Mrs. W.P.O. Isibor for their selfless financial support.

\section{COMPETING INTERESTS}

Author has declared that no competing interests exist.

\section{REFERENCES}

1. Adebola OT, Olaniyan RF. Relative abundance and identification of Palaemonid Prawns at Oluwa Creek, Igbokoda, South West, Nigeria. Journal of Science and Science Education, Ondo. 2012;3(1):118-124.

2. Eniade AA, Bello-Olusoji AO. The Abiotic Ecology of breeding ground of palaemonid prawns in the Ilaje Estuary, Ondo State, Nigeria. Continental Journal of Fisheries and Aquatic Science. 2011;5(1):31-37.

3. Arimoro FO, Meye JA. Some aspects of the biology of Macrobrachium dux (lenz, 1910) (CRUSTACEA DECAPODA; NANTA) in River Orogodo, Niger Delta., Nigeria. Department of Zoology, Delta State University. P.M.B. 1, Abraka, Nigeria. Acta- boil colomb. 2007;12(2).

4. Isibor PO, Oluowo EF. Evaluation of some heavy metals and total petroleum hydrocarbon in water and palaemonid shrimps (Macrobrachium vollenhovenii) of Egbokodo River, Warri, Delta State, Nigeria. Science Domain Journal of Applied Life Sciences International. 2016. 6(4):1-12.

DOI: $10.9734 / J A L S I / 2016 / 27148$

5. Moses BS. Fisheries and ecotourism: A tool for national development. FISON 
Conference Proceedings. Edited by UI. Enim; 2006.

6. Dirisu A, Olomukoro JO. Macroinvertebrate community and pollution tolerance index in edion and Omodo Rivers in derived Savannah Wetlands in Southern Nigeria. Jordan Journal of Biological Sciences. 2014;7(1):19-24.

7. Atz J. Intersexuality in fishes. In: Amstrong CN, Marshall AJ. (eds). Vertebrates including man. London Academic Press; 1964.

8. Harrington RWJR. Environmentally controlled induction of primary male gonochorists from eggs of self-fertilizing fish, Rivulies marmoralus. Poet BiolBull InterBiol. Lah woods Hole; 1967.

9. Andem AB, Udofia UU, Okorafor AA, George UU. Bioaccumulation and some heavy metals and total hydrocarbons (THC) in the tissues of some Periwinkles (Tympanotomus fuscatus var radula) in the intertidal regions of Qua lboe River Basin, Ibeno, Akwa Ibom State, Nigeria. Greener Journal of Biological Sciences. 2013;3(7): 253-259.

10. Ayenimo JG, Adeyinwo CA, Amoo IA, Odukudu FI. A preliminary investigation of heavy metals in periwinkles from Warri River, Nigeria. Journal of Applied Science. 2005;5(5):813-815.

11. Emeribe CN, Ogbomida ET, Fasipe OA, Biose O, Aganmwonyi I, Isiekwe M, Fasipe IP. Hydrological assessments of some rivers in Edo State, Nigeria; for small-scale hydropower development. Nigerian Journal of Technology. 2016;35(3):656- 668 .

12. Sakpa S, Ikejimba CC. Comparative study of some heavy metals' concentrations in water and Tympanotonus fuscatus var radula samples of Egbokodo River, Warri,
Nigeria. International Journal of Modern Biological Research (Int. Mod. Biol. Res.). IJMBR. 2014;2(2014):7-15.

13. Imoobe TOT, Adeyinka ML. Zooplanktonbased assessment of the trophic state of a tropical forest river in Nigeria. Arch. Biol. Sci. Belgrade. 2009;61(4):733-740.

14. Kogbe CA, Mehes K, Salam MB. Biostratigraphy of upper cretaceous and tertiary sediment penetrated by Gbekebo "B" well, Niger Delta, Nigeria. In: Geology of Nigeria (C.A. Kogbe, ed.) Elizaberthan Publishing Company, Lagos. 1976;352.

15. Food and Agricultural Agency (FAO). Species identification sheets for Fisheries purposes on Eastern Central Atlantic; fishing areas 34, 47. Edited (in part) by Fischer, W. G, Bianch and W.B. Scott (eds). 1981: Canada Funds in-Trust Ottawa, Department of Fisheries and Oceans Canada, by arrangement with the food and Agricultural Organization of the United Nations. 1981;1-7.

16. Powel CB. Freshwater and brackish water shrimps of economic importance in the Niger Delta. In Proceedings of $2^{\text {nd }}$ annual conference of the fisheries society of Nigeria, Calabar. 1982;254-285.

17. Bello Olusoji OA, Ariyo $\mathrm{T}$, Arinola A. Taxonomical studies on rocky freshwater prawns at erin-ijesha waterfalls. Journal of Food, Agricultural and Environment. 2004; 2(3\&4):280-283.

18. American Public Health Association (APHA). Standard methods for the examination of water and waste water. $21^{\text {st }}$ Edition. American Public Health Association, Washington, DC; 2005.

19. Federal Environmental Protection Agency (FEPA). Guidelines and standards for environmental pollution control in Nigeria. 2003;420.

(c) 2016 Omoregie; This is an Open Access article distributed under the terms of the Creative Commons Attribution License (http://creativecommons.org/licenses/by/4.0), which permits unrestricted use, distribution, and reproduction in any medium, provided the original work is properly cited.

Peer-review history:

The peer review history for this paper can be accessed here: http://sciencedomain.org/review-history/16994 